\title{
Elevated Levels of SREBP-2 and Cholesterol Synthesis in Livers of Mice Homozygous for a Targeted Disruption of the SREBP-1 Gene
}

\author{
Hitoshi Shimano, ${ }^{*}$ lichiro Shimomura, ${ }^{*}$ Robert E. Hammer, ${ }^{\ddagger}$ Joachim Herz, ${ }^{\star}$ Joseph L. Goldstein, ${ }^{\star}$ Michael S. Brown, \\ and Jay D. Horton* \\ *Department of Molecular Genetics, ${ }^{\ddagger}$ Department of Biochemistry, and ${ }^{\S}$ Howard Hughes Medical Institute, University of Texas \\ Southwestern Medical Center, Dallas, Texas 75235
}

\begin{abstract}
The synthesis of cholesterol and its uptake from plasma LDL are regulated by two membrane-bound transcription factors, designated sterol regulatory element binding protein-1 and -2 (SREBP-1 and SREBP-2). Here, we used the technique of homologous recombination to generate mice with disruptions in the gene encoding the two isoforms of SREBP-1, termed SREBP-1a and SREBP-1c. Heterozygous gene-disrupted mice were phenotypically normal, but 50$85 \%$ of the homozygous $(-I-)$ mice died in utero at embryonic day 11 . The surviving $-/-$ mice appeared normal at birth and throughout life. Their livers expressed no functional SREBP-1. There was a 1.5 -fold upregulation of SREBP-2 at the level of mRNA and a two- to threefold increase in the amount of mature SREBP-2 in liver nuclei. Previous studies showed that SREBP-2 is much more potent than SREBP-1c, the predominant hepatic isoform of SREBP-1, in activating transcription of genes encoding enzymes of cholesterol synthesis. Consistent with this observation, the SREBP-1 $-I-$ animals manifested elevated levels of mRNAs for 3-hydroxy-3-methylglutaryl coenzyme A synthase and reductase, farnesyl diphosphate synthase, and squalene synthase. Cholesterol synthesis, as measured by the incorporation of $\left[{ }^{3} \mathrm{H}\right]$ water, was elevated threefold in livers of the $-I-$ mice, and hepatic cholesterol content was increased by $\mathbf{5 0 \%}$. Fatty acid synthesis was decreased in livers of the $-I-$ mice. The amount of white adipose tissue was not significantly decreased, and the levels of mRNAs for lipogenic enzymes, adipocyte lipid binding protein, lipoprotein lipase, and leptin were normal in the $-I-$ mice. We conclude from these studies that SREBP-2 can replace SREBP-1 in regulating cholesterol synthesis in livers of mice and that the higher potency of SREBP-2 relative to SREBP-1c leads to excessive hepatic cholesterol synthesis in these animals. (J. Clin. Invest. 1997. 100:2115-2124.) Key words: cholesterol • low density lipoprotein $\bullet$ sterol regulatory element binding proteins $\bullet$ fatty acids $\bullet$ targeted homologous recombination
\end{abstract}

\footnotetext{
Address correspondence to Joseph L. Goldstein, M.D., Department of Molecular Genetics, University of Texas Southwestern Medical Center, 5323 Harry Hines Blvd., Room L5-238, Dallas, TX 75235. Phone: 214-648-2141; FAX: 214-648-8804.

Received for publication 6 June 1997 and accepted in revised form 22 August 1997.
}

J. Clin. Invest.

(C) The American Society for Clinical Investigation, Inc. 0021-9738/97/10/2115/10 \$2.00

Volume 100, Number 8, October 1997, 2115-2124

http://www.jci.org

\section{Introduction}

A pair of transcription factors called sterol regulatory element binding proteins (SREBPs) ${ }^{1}$ are essential for the synthesis of cholesterol and its uptake from LDL in all cultured cells so far studied, including Chinese hamster ovary (CHO) cells (for review see reference 1). CHO cells with mutations that disrupt the functioning of both SREBP-1 and SREBP-2 are unable to synthesize cholesterol or to take it up from plasma LDL $(1,2)$. Such cells cannot survive unless cholesterol is added to the culture medium in a form that allows uptake by nonspecific lowefficiency mechanisms. On the other hand, mutations that prevent downregulation of SREBP-1 and -2 lead to massive overaccumulation of cholesterol within the cell $(1,3)$. Preliminary evidence indicates that SREBP-1 (but not SREBP-2) may play a different role in liver than it does in cultured cells $(1,4)$. The current studies were designed to investigate this difference through the use of gene knockout technology.

In cultured cells the activities of the SREBPs are regulated by an exquisitely sensitive two-step proteolytic pathway (1). The SREBPs are synthesized as membrane-bound precursors of $\sim 1,150$ amino acids that contain three segments. The $\mathrm{NH}_{2}-$ terminal segment of $\sim 480$ amino acids is a transcription activator of the basic-helix-loop-helix-leucine zipper (bHLH-Zip) family. The extreme $\mathrm{NH}_{2}$ terminus of this segment is an acidic sequence that acts as an activation domain. The middle segment of the SREBPs consists of $\sim 80$ amino acids that comprise two membrane-spanning sequences separated by a short hydrophilic sequence of 31 amino acids. The $\mathrm{COOH}$-terminal half of the protein, designated regulatory domain, consists of $\sim 590$ amino acids that have no resemblance to any known protein. This domain is required for the sterol-regulated cleavage of the SREBPs (discussed below).

The SREBPs are bound to membranes of the nuclear envelope and endoplasmic reticulum in such a way that the $\mathrm{NH}_{2}-$ terminal and $\mathrm{COOH}$-terminal segments face the cytoplasm and the hydrophilic 31 amino acid segment, known as the lumenal loop, projects into the lumen of these organelles $(1,5)$. In sterol-deprived cells a protease cuts the SREBPs in the lumenal loop, separating the $\mathrm{NH}_{2}$-terminal and $\mathrm{COOH}$-terminal segments, but leaving both attached to the membrane. This allows a second protease (Site-2 protease) to cut the $\mathrm{NH}_{2}$-terminal fragment at a site within the first transmembrane sequence,

1. Abbreviations used in this paper: $\mathrm{aP} 2$, adipocyte lipid binding protein; bHLH-Zip, basic-helix-loop-helix-leucine zipper; CHO, Chinese hamster ovary; dpc, days post coitum; ES, embryonic stem; GAPDH, glyceraldehyde-3-phosphate dehydrogenase; HMG CoA, 3-hydroxy3-methylglutaryl coenzyme A; HSL, hormone-sensitive lipase; HSV TK, herpes simplex virus thymidine kinase; LPL, lipoprotein lipase; p.c., post coitum; SCD, stearoyl CoA desaturase; SREBP, sterol regulatory element binding protein. 
thereby liberating the $\mathrm{NH}_{2}$-terminal segment so that it can enter the nucleus $(1,2)$. This $\mathrm{NH}_{2}$-terminal segment, known as the mature form of SREBP, activates transcription of genes encoding 3-hydroxy-3-methylglutaryl coenzyme A (HMG CoA) synthase, HMG CoA reductase, farnesyl diphosphate synthase, squalene synthase, and other enzymes of cholesterol biosynthesis. It also activates transcription of the gene encoding the LDL receptor. The mature form of the SREBPs also activates genes encoding enzymes of fatty acid biosynthesis, including acetyl coenzyme A carboxylase, fatty acid synthase, and stearoyl coenzyme A desaturase-1 (for review see reference 1). $\mathrm{CHO}$ cells with defects in the action of the Site-2 protease are auxotrophic for sterols and unsaturated fatty acids $(2,6)$.

Three forms of SREBPs are currently recognized (1). SREBP-1a and -1c arise from a single gene through use of alternate promoters that give rise to alternate first exons (7). SREBP-1a has a longer $\mathrm{NH}_{2}$-terminal acidic activation domain than $-1 \mathrm{c}$, and it is much more active in stimulating transcription (8). SREBP-2 arises from a separate gene (9), and it has a long activation domain similar to that of SREBP-1a (10). In tissue culture cells, SREBP-1a and -2 are the predominant transcripts (11). They are regulated coordinately, and they appear to act independently, although they are capable of forming heterodimers in vitro (1).

In addition to their roles in stimulating transcription, the SREBPs have been implicated in enhancing the differentiation of adipocytes in tissue culture. Kim and Spiegelman (12) overproduced ADD1, which is the rat equivalent of SREBP-1c (11), in cultured NIH3T3 preadipocytes and observed increased differentiation into fat-laden adipocytes.

The roles of SREBPs in liver are less well-established than their roles in cultured cells. In livers of mice and hamsters on a normal chow diet, the predominant mRNA form of SREBP is the relatively inactive $-1 \mathrm{c}$ isoform, which exceeds the $-1 \mathrm{a}$ isoform by ninefold $(1,11)$. The SREBP-2 isoform is also limited in amount. When the livers are deprived of cholesterol by treatment with cholesterol synthesis inhibitors and bile acid binding resins, the amount of the SREBP-2 protein increases, and the efficiency of its proteolytic processing increases. At the same time there is a paradoxical and reciprocal decline in the total amount of SREBP-1c and its proteolytic processing becomes less efficient $(1,4)$. The exchange of SREBP-2 for SREBP-1c in the nucleus is associated with an elevation in the mRNAs for several target genes, including the LDL receptor, HMG CoA reductase, and HMG CoA synthase. These data suggest that SREBP-2 is regulated in liver as it is in cultured cells, but SREBP-1 is regulated differently (1).

The consequences of unregulated SREBP action in liver were tested by producing transgenic mice that overexpress a dominant positive form of SREBP-1a (13). The truncated protein terminated at residue 460 , and thus it included the entire bHLH-Zip domain but lacked the transmembrane segment. The protein entered the nucleus constitutively without requiring proteolysis, and thus it could not be downregulated in response to cholesterol overaccumulation. As a result, the liver became massively enlarged, owing to massive accumulation of triglycerides and cholesteryl esters. The mRNAs for all of the regulated lipogenic enzymes were increased markedly, and the livers produced cholesterol and fatty acids at rates that were fivefold and 20-fold above control levels (13). Interestingly, transgenic mice that produced the corresponding fragment of SREBP-1c showed no increase in the cholesterologenic en- zymes and only a moderate increase in the enzymes of fatty acid biosynthesis (8).

To determine more precisely the requirements for SREBPs in liver, in the current experiments we have used homologous recombination to inactivate the gene for SREBP-1 (both the -1a and $-1 \mathrm{c}$ isoforms) in mouse liver. Most of the homozygous knockout animals died in utero, but a small number survived. These survivors exhibited an increase in the amount of SREBP-2 in the liver, and this was associated with an overproduction of cholesterol.

\section{Methods}

Materials and general methods. Unless otherwise indicated, DNA manipulations were performed by standard molecular techniques (14). Embryonic stem (ES) cells were derived from 129Sv embryos. The content of cholesterol and triglycerides in plasma and liver was measured as described previously (13). Other materials and general methods have been described previously $(8,13)$.

Cloning of mouse SREBP-1 cDNA and gene. Partial cDNAs encoding the $5^{\prime}$ untranslated region and the $\mathrm{NH}_{2}$-terminal domain of mouse SREBP-1a and -1c corresponding to amino acids 1-378 of hamster SREBP-1 (15) were cloned as described previously $(11,13)$. Another overlapping partial cDNA encoding a fragment of mouse SREBP-1 corresponding to amino acids 344-765 of hamster SREBP-1 was obtained by reverse transcriptase-PCR using first strand cDNA from mouse liver poly $(\mathrm{A})^{+} \mathrm{RNA}$ as a template and primers derived from conserved human and hamster SREBP-1 sequences, as follows: 5' primer, 5'-GTGGTGGGCACTGAGGCAAAGCTGAATAAA-3', corresponding to amino acids 344-353 of hamster SREBP-1; and $3^{\prime}$ primer, 5'-CCAGTCCCCATCCACGAAGAAACGGTGGCC-3', corresponding to amino acids 756-765 of hamster SREBP-1 (15). The PCR product was cloned into pCRII using a TA cloning Kit (Invitrogen Corp., San Diego, CA) and sequenced.

A genomic mouse SREBP-1 clone was obtained from 129/ola mouse strain P1 genomic library (Genome Systems Inc., St. Louis, $\mathrm{MO})$. The 222-bp probe used for screening the P1 library was produced by PCR using 129Sv/Ev mouse genomic DNA as template and the following primers derived from the mouse SREBP-1 sequence: $5^{\prime}$ primer, 5'-ACCCTGGTGAGTGGAGGGACCATCTTGG-3', and 3' primer, 5'-CTTTGCTTCAGTGCCCACCACCAGGTCTTT-3', corresponding to amino acids 277-286 and 341-350 of hamster SREBP-1, respectively. A genomic map based on Southern blot analysis and sequencing indicated that this clone covers all exons encoding mouse SREBP-1 except exon 1a. The exon-intron structure of the mouse SREBP-1 gene (Fig. 1) was basically identical to that of the human SREBP-1 gene (7).

Construction of targeting vectors for SREBP-1 gene disruption. Two targeting constructs of the replacement type were produced (Fig.1, $A$ and $B$ ). In both constructs, the PolIIsneobp $A$ expression cassette and two copies of the herpes simplex virus thymidine kinase (HSV TK) gene were inserted for selection markers (16). A XhoI fragment $(0.8 \mathrm{~kb})$ containing a part of exon 2 and a BamHI fragment $(0.75 \mathrm{~kb})$ containing exon 12 and a part of exon 13 were subcloned from the P1 clone containing the mouse SREBP-1 gene and used for the short arm of targeting Constructs A and B, respectively (Fig. 1). An EcoRI fragment ( $12.5 \mathrm{~kb}$ ) extending from intron 2 to the $3^{\prime}$-untranslated region and a SacI fragment $(10.7 \mathrm{~kb})$ extending from the intron separating exons $1 \mathrm{a}$ and $1 \mathrm{c}$ to exon 5 were subcloned and used for the long arm of targeting Constructs $\mathrm{A}$ and $\mathrm{B}$, respectively. The short arm and long arm were each ligated into either side of the PolIIsneobp $A$ cassette. The transcriptional orientation of the neo gene was opposite to that in the SREBP-1 gene in Construct A and the same in Construct $\mathrm{B}$. The integrity of both vectors was confirmed by sequencing all ligation junctions.

ES cell culture and generation of mice homozygous for the disrupted SREBP-1 gene. ES cells (JH-1 and SM-1) were cultured on 

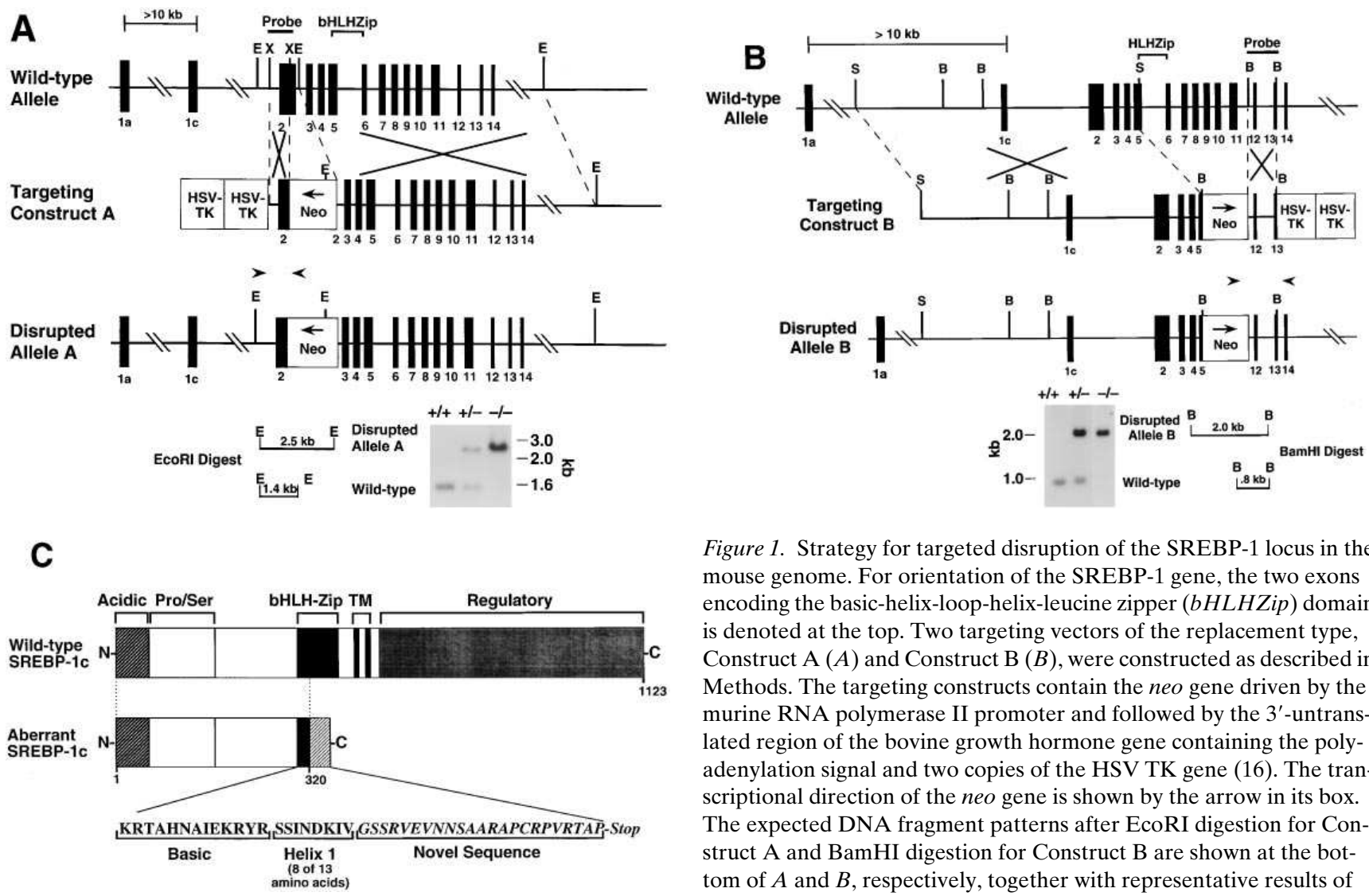

Figure 1. Strategy for targeted disruption of the SREBP-1 locus in the mouse genome. For orientation of the SREBP-1 gene, the two exons encoding the basic-helix-loop-helix-leucine zipper ( $b H L H Z i p)$ domain is denoted at the top. Two targeting vectors of the replacement type, Construct $\mathrm{A}(A)$ and Construct $\mathrm{B}(B)$, were constructed as described in Methods. The targeting constructs contain the neo gene driven by the murine RNA polymerase II promoter and followed by the 3 '-untranslated region of the bovine growth hormone gene containing the polyadenylation signal and two copies of the HSV TK gene (16). The transcriptional direction of the neo gene is shown by the arrow in its box. The expected DNA fragment patterns after EcoRI digestion for Construct $\mathrm{A}$ and $\mathrm{BamHI}$ digestion for Construct $\mathrm{B}$ are shown at the bottom of $A$ and $B$, respectively, together with representative results of Southern blot analysis of tail DNAs from wild-type $(+/+)$, heterozygous (+/-), and homozygous ( $-/-)$ mice for the disrupted SREBP-1 alleles A and B. The DNA probes used for Southern analysis, a 0.8-kb XhoI genomic fragment for Construct A and a 0.7-kb BamHI genomic fragment for Construct B, are shown. The positions of the two oligonucleotides used for PCR detection of homologous recombination are indicated by the arrowheads. $C$ shows a diagram of the domain structure of the aberrant mouse SREBP-1c protein encoded by the SREBP-1 gene disrupted by targeting Construct B. The aberrant SREBP proteins encoded by the disrupted SREBP-1 allele B are truncated at the valine residue that corresponds to amino acid 320 in human SREBP-1c and amino acid 344 in human SREBP-1a, followed by 23 novel amino acids and a stop codon derived from the mouse PolII sequence in the neo cassette.

$E$, EcoRI; $X$, XhoI; $B$, BamHI; $S$, SacI.

leukemia inhibitory factor-producing STO feeder cells (16). Approximately $2 \times 10^{7}$ cells were electroporated $(275 \mathrm{~V}, 330 \mu \mathrm{F}$; GIBCO BRL Electroporator; GIBCO BRL, Gaithersburg, MD) with $50 \mu \mathrm{g} / \mathrm{ml}$ of each targeting vector (linearized with SalI) and seeded onto irradiated feeder layers. The ES cells were subjected to selection with 190 $\mu \mathrm{g} / \mathrm{ml} \mathrm{G} 418$ and $0.25 \mu \mathrm{M} 1$-[2-deoxy-2-fluoro- $\beta$-D-arabinofuranosyl]5-iodouracil (Bristol-Myers Squibb Pharmaceuticals, Princeton, NJ). Recombinant clones were identified by PCR using a primer located in the $3^{\prime}$ untranslated region of the neo cassette, 5'-GATTGGGAAGACAATAGCAGGCATGC-3', together with one of the following primers: a primer located in the intron between exon $1 \mathrm{c}$ and exon 2 , 5'-GCCCCTGCCTCCCAAGTACTGGGATTAAAG-3' for detection of the disrupted SREBP-1 allele A, or a primer located in exon 13, 5' -ACGCTCGCTCTAGGAGATGTTCACGGAATA-3', for detection of the disrupted SREBP-1 allele B (Fig. 1, arrowheads). Homologous recombination was verified by Southern analysis after EcoRI and BamHI digestion for targeting Constructs A and B, respectively, and probing with the indicated probe in Fig. 1. Five and four independent ES cell clones containing the disrupted SREBP-1 alleles $\mathrm{A}$ and $\mathrm{B}$, respectively, were established and injected into C57BL/6J blastocysts, yielding a total of 22 and 15 chimeric males whose coat color (agouti) indicated a contribution of ES cells ranging from $25-100 \%$. Of the 22 chimeric males, 21 were fertile, and 7 gave offspring that carried the disrupted SREBP-1 allele A through the germline. Of the 15 chimeric males, 15 were fertile, and 6 gave offspring that carried the disrupted SREBP-1 allele B through the germline. Four and three lines with disrupted SREBP-1 alleles A and B, respectively, were bred and used for analysis. All experiments were performed with the F2 or F3 generation descendants, which were hybrids between the C57BL/6J and 129Sv/Ev strains.

Mice were housed in colony cages and maintained on a 14-h light/ 10-h dark cycle. Mice were fed Teklad 4\% (wt/wt) Mouse/Rat Diet 7001 from Harlan Teklad Premier Laboratory Diets (Madison, WI) and were killed in the nonfasting state during the early phase of the light cycle, unless otherwise indicated.

Construction of expression vectors. HSV TK-driven expression plasmids, designated pTK- SREBP-1a487 and pTK-SREBP-1c463, encoding truncated versions of mouse SREBP-1a and -1c corresponding to amino acids 1-487 and 1-463 of human SREBP-1 (15), respectively, were constructed as follows. First strand cDNA from mouse liver poly(A) ${ }^{+}$RNA was prepared as described previously and used as a template for PCR $(8,13)$. Primers used were as follows: $5^{\prime}$ primer for pTK-SREBP-1a487 containing a NotI site, 5'-AAAGCGGCCGCCATGGACGAGCTGGCCTTCGGT-3'; 5' primer for pTKSREBP-1c463 containing a NotI site, $5^{\prime}$-AAAGCGGCCGCACCACGGAGCCATGGATTGCACATT-3'; and 3' primer for both plasmids containing an XbaI site and a stop codon, 5'-AAATCTAGACTAGCGGGAGCGGTCCAGCATGCCTCGACTGTG-3'. The 
PCR products were subcloned into the NotI-XbaI sites of pTK-HSVBP2 (8).

cDNA cloning of aberrant SREBP-1 mRNAs. To clone cDNAs corresponding to the two mRNAs derived from disrupted allele $\mathrm{B}$, we isolated total RNA from the liver of a $\mathrm{B}^{-1-}$ mouse. After first strand synthesis with reverse transcriptase, we performed two separate PCRs. The $5^{\prime}$ primer in one case corresponded to the $5^{\prime}$ end of the SREBP-1a mRNA, and in the other case it corresponded to the $5^{\prime}$ end of SREBP-1c. Both reactions used the same 3' primer, which was derived from the sequence of the PolII promoter, which was at the $5^{\prime}$ end of the neo insertion cassette. This primer had an XbaI linker at the $3^{\prime}$ end. Its sequence was 5'-AAATCTAGACCCTTGCGCTACGGGGCCGTCCGCACCGG-3'. Gel electrophoresis revealed bands of the appropriate size in both reactions, but the product with the SREBP-1c primer was at least 10 -fold more intense than the band derived from the SREBP-1a primer. Both products were cloned into the NotI-XbaI sites of pTK-HSV-BP2 (8). The junctional regions of both plasmids were sequenced, and this confirmed that both plasmids encoded the authentic SREBP-1 sequence up to codon 344 for SREBP1a and up to codon 320 for SREBP-1c. Thereafter, the sequence continued into the sequence of the PolII promoter as shown in Fig. 1 C. These two plasmids were used for the expression studies shown in Fig. 3.

Transfections and luciferase assays. Human embryonic kidney 293 cells were grown in monolayer at $37^{\circ} \mathrm{C}$ in an atmosphere of $8-9 \%$ $\mathrm{CO}_{2}$ in medium A (DME containing $100 \mathrm{U} / \mathrm{ml}$ penicillin and $100 \mu \mathrm{g} / \mathrm{ml}$ streptomycin sulfate) supplemented with $10 \%$ (vol/vol) FCS. The indicated amount of each expression plasmid was transfected into 293 cells simultaneously with $0.4 \mu \mathrm{g}$ of a luciferase reporter plasmid (pHMGCoA Syn-Luc) (8) and $0.2 \mu \mathrm{g}$ of a control pCMV $\beta$-gal reference plasmid. The total amount of DNA in each transfection was adjusted to $5 \mu \mathrm{g}$ per dish with vector DNA as described previously (8). Transfection studies were carried out with cells plated on $60-\mathrm{mm}$ dishes. On day $0,4 \times 10^{5}$ cells were plated in medium A with $10 \%$ FCS. On day 2, duplicate dishes of cells were transfected by the calcium phosphate method with a Stratagene MBS kit according to the manufacturer's protocol. $3 \mathrm{~h}$ after transfection, the cells were washed once with PBS and fed with $5 \mathrm{ml}$ of medium A supplemented with $10 \%$ FCS, $1 \mu \mathrm{g} / \mathrm{ml}$ 25-hydroxycholesterol, and $10 \mu \mathrm{g} / \mathrm{ml}$ cholesterol (added in a final concentration of $0.2 \%$ ethanol). After $16 \mathrm{~h}$, the cells in each dish were washed once with PBS. One set of duplicate dishes was used for immunoblot analysis, and another set of duplicate dishes was subjected to luciferase and $\beta$-galactosidase assays using a kit (Promega Corp., Madison, WI and GIBCO BRL, respectively) as described previously (8). The amount of luciferase activity in transfectants (relative light units) was normalized to the amount of $\beta$-galactosidase activity (OD units).

Immunoblotting. A rabbit polyclonal antibody against mouse SREBP-2 (amino acids 32-250) was prepared as described previously for mouse SREBP-1 (13). Rabbits were immunized with a His(6)tagged protein containing amino acids $32-250$ of mouse SREBP-2 that was bacterially produced using Expressor System (QIAGEN, Inc., Chatsworth, CA). Nuclear extracts and membrane ( $10^{5}$-g pellet) fractions were prepared from mouse livers as described previously (13). Aliquots $(30 \mu \mathrm{g}$ protein) of the membranes and nuclear extract fractions were subjected to $8 \%$ SDS-PAGE, transferred to Hybond C extra membranes (Amersham Corp., Arlington Heights, IL), and incubated with $5 \mu \mathrm{g} / \mathrm{ml}$ rabbit anti-mouse SREBP-1 IgG (directed against amino acids 32-250 of SREBP-1a and 8-226 of SREBP-1c; 13) or antimouse SREBP-2 IgG (see above). The membrane-bound antibodies were visualized with the Enhanced Chemiluminescence Western Blotting Detection System kit (Amersham Corp.) using a horseradish peroxidase-labeled donkey anti-rabbit IgG antibody (Amersham Corp.). Protein content of samples was determined with the BCA Kit (Pierce Chemical Co., Rockford, IL).

Blot hybridization of RNA. cDNA probes for mouse farnesyl diphosphate (FPP) synthase and microsomal triglyceride transfer protein (MTP) were prepared with reverse transcriptase-PCR and mouse liver poly $(\mathrm{A})^{+}$RNA as template as described previously for other probes (13). cDNA probes for mouse lipoprotein lipase (LPL), hormone sensitive lipase (HSL), leptin, and the adipocyte lipid binding protein (aP2) were prepared from mouse epididymal fat total RNA. The PCR primers used were as follows: FPP synthase: $5^{\prime}$ primer, 5'-GGTCCTGGAGTACAACACTGTAGGAGGCAA-3', and $3^{\prime}$ primer, 5'-TGGCAGCCGCGATAGGCAGGTAGAAAGAGT-3' (17); MTP: 5' primer, 5'-GACATCAGGGAAACCGTTATGAT- $3^{\prime}$, and $3^{\prime}$ primer, 5'-AATGGACAGCAGAATGTTCTTCACATCCAT-3' (18); LPL: 5' primer, 5'-GTGGCCGCAGCAGACGCAGGAAGA-3', and $3^{\prime}$ primer, 5'-ATGCGAGCACTTCACCAGCTGGTC-3' (19); HSL: 5' primer, 5'-ACCTGAGGCCTTTGAGATGCCACTC-3', and $3^{\prime}$ primer, 5'-CACTCCATAGGCTGCTGCCCGAAG-3' (20); leptin: 5' primer, 5'-ATCAACAGGTCCTCACCAGCC-3', and $3^{\prime}$ primer, 5'-GCTGAAGAACTAGGTGAGAGT-3' (21); aP2: 5' primer, 5'-CTCCTGTGCTGCAGCCTTTCTC-3', and $3^{\prime}$ primer, 5'-CGTAACTCACCACCACCAGCTTGTC-3' (22).

Total RNA was prepared from mouse liver using an RNeasy ${ }^{\mathrm{TM}}$ Total RNA kit (QIAGEN Inc.) and from adipose tissue by the guanidinium thiocyanate/phenol/chloroform method (23). Equal aliquots of total RNA from mice in each group were pooled (total, $15 \mu \mathrm{g}$ ), denatured with formaldehyde and formamide, and subjected to Northern blot analysis with the indicated cDNA probe. cDNA probes were prepared as described previously (13) and radiolabeled with $\left[\alpha-{ }^{32} \mathrm{P}\right]$ CTP $(3,000 \mathrm{Ci} / \mathrm{mmol})$ using Megaprime DNA Labeling System (Amersham Corp.). The filters were hybridized with the indicated ${ }^{32}$ P-labeled probes $\left(\sim 1 \times 10^{6} \mathrm{cpm} / \mathrm{ml}\right)$ for $2 \mathrm{~h}$ at $65^{\circ} \mathrm{C}$ using Rapidhyb buffer (Amersham Corp.), washed with $0.1 \%$ (wt/vol) SDS $/ 0.1 \times$ $\mathrm{SSC}$ at $70^{\circ} \mathrm{C}$ for $60 \mathrm{~min}$, and exposed to Reflection ${ }^{\mathrm{TM}} \mathrm{NEF} 496$ film (Dupont-NEN, Boston, MA) with intensifying screens at $-80^{\circ} \mathrm{C}$. The resulting bands were quantified by exposure of the filter to a BioImaging Analyzer with BAS1000 MacBus software (Fuji Medical Systems, Standish, ME), and the results were normalized to the signal generated from glyceraldehyde-3-phosphate dehydrogenase (GAPDH) mRNA.

Cholesterol and fatty acid synthesis in vivo. Eight 20-wk-old mice homozygous for the disrupted SREBP-1 allele B and wild-type mice of the same genetic background (four females and four males for each group) were killed during the early light cycle. The rates of cholesterol and fatty acid synthesis in livers and adrenal glands were measured after intraperitoneal injection of $\left[{ }^{3} \mathrm{H}\right]$ water and saponification of either $200-300 \mathrm{mg}$ aliquots of liver or both adrenal glands as described previously (13). Briefly, fatty acids were extracted from each sample with two $15-\mathrm{ml}$ hexane extractions after acidification with $1 \mathrm{ml}$ of concentrated $\mathrm{HCl}$. The rates of hepatic cholesterol synthesis and fatty acid synthesis were calculated as $\mu \mathrm{mol}$ of $\left[{ }^{3} \mathrm{H}\right]$ water incorporated into digitonin-precipitable sterols or fatty acids/h per gram of tissue.

\section{Results}

We were unable to design a vector that could destroy the $5^{\prime}$ end of the SREBP-1 gene because the SREBP-1a and - $1 \mathrm{c}$ transcripts use different promoters that are separated by more than $10 \mathrm{~kb}$ in the mouse and human genomes $(7,11)$. Instead, we produced two different targeting constructs, each of which is expected to functionally inactivate both the SREBP-1a and -1c transcripts. The structures of these targeting vectors are shown in Fig. 1.

Targeting Construct A inserts the neo gene into the middle of exon 2 (Fig. $1 \mathrm{~A}$ ). If the disrupted gene is transcribed and translated, it should produce a protein fragment whose sequence terminates within the neo sequence in exon 2. If either exon 1a or 1c were to splice into exon 3 , bypassing the disrupted exon 2 , it would produce an in frame transcript whose 
Table I. Segregation of Disrupted SREBP-1 Alleles in Mice

\begin{tabular}{ccrrrrrr}
\hline & & \multicolumn{5}{c}{$\begin{array}{c}\text { Genotype of } \\
\text { offspring }\end{array}$} \\
\cline { 5 - 7 } Mating & $\begin{array}{c}\text { Age of } \\
\text { offspring }\end{array}$ & Litters & $+/+$ & $+/-$ & $-/-$ & $\begin{array}{c}\text { Resorption } \\
\text { sites }\end{array}$ \\
\hline Disrupted allele A & & No. & & No. & No. \\
$+/-\mathrm{M} \times+/-\mathrm{F}$ & $9.5 \mathrm{dpc}$ & 6 & 20 & 40 & 17 & 0 \\
$+/-\mathrm{M} \times+/-\mathrm{F}$ & $10.5 \mathrm{dpc}$ & 5 & 19 & 26 & 12 & 0 \\
$+/-\mathrm{M} \times+/-\mathrm{F}$ & $11.5 \mathrm{dpc}$ & 4 & 5 & 21 & 4 & 5 \\
$+/-\mathrm{M} \times+/-\mathrm{F}$ & $14.5 \mathrm{dpc}$ & 4 & 10 & 20 & 3 & 15 \\
$+/-\mathrm{M} \times+/-\mathrm{F}$ & $16.5 \mathrm{dpc}$ & 2 & 2 & 9 & 0 & 8 \\
$+/-\mathrm{M} \times+/-\mathrm{F}$ & $18.5 \mathrm{dpc}$ & 4 & 3 & 7 & 0 & 16 \\
$+/-\mathrm{M} \times+/-\mathrm{F}$ & Adult & 43 & 86 & 180 & 12 & $*$ \\
$-/-\mathrm{M} \times+/-\mathrm{F}$ & Adult & 9 & $*$ & 52 & 7 & $*$ \\
Disrupted allele $\mathrm{B}$ & & & & & & \\
$+/-\mathrm{M} \times+/-\mathrm{F}$ & Adult & 26 & 45 & 84 & 26 & $*$ \\
$-/-\mathrm{M} \times+/-\mathrm{F}$ & Adult & 22 & $*$ & 62 & 25 & $*$ \\
\hline & & & & & & \\
\hline
\end{tabular}

Genotype was determined by Southern blot analysis (Fig. 1) of DNA prepared from tails of adult mice or from whole embryos at the indicated day post coitum $(d p c)$. Not applicable.

coding sequence would lack exon 2. Fig. $1 A$ shows an EcoRI digest of genomic DNA from mice that are heterozygous and homozygous for the disruption in exon 2 . The predicted $2.5-\mathrm{kb}$ EcoRI fragment is seen in homozygous form in the $-/-$ animals and in heterozygous form in the $+/-$ animals. These mice are designated $\mathrm{A}^{-1-}$ and $\mathrm{A}^{+/-}$, respectively.

Fig. $1 B$ shows a diagram of Targeting Construct B. Homologous recombination with the wild-type SREBP-1 allele results in a deletion that begins in the middle of exon 5 and proceeds through exon 11 . If a protein were translated from this disrupted allele, it would lack the HLH-Zip domain, and it would not be expected to bind DNA or to activate transcription. Fig. $1 B$ shows a BamHI digest of genomic DNA from mice bearing the disrupted gene. The $-/-$ animals have the predicted $2.0-\mathrm{kb}$ fragment denoting the presence of the disrupted allele, whereas the $+/-$ animals have evidence for both the disrupted allele (2.0-kb fragment) and the wild-type allele (0.8-kb fragment). These animals are designated $\mathrm{B}^{-1-}$ and $\mathrm{B}^{+/-}$, respectively.

Each of the targeting constructs was introduced into ES cells by electroporation, and homologous recombinants were selected by standard techniques as described in Methods. Clones of cells were injected into mouse blastocysts, and chimeric offspring were bred to produce $\mathrm{A}^{+/-}$or $\mathrm{B}^{+/-}$mice. Table I shows the results of breeding experiments in which heterozygous animals were mated, and the pregnant females were killed on various days post coitum (p.c.). When $\mathrm{A}^{+/-}$mice were interbred, the number of embryos was normal through day 10.5 p.c., and the distribution of genotypes was consistent with Mendelian segregation. Thereafter, the number of living $\mathrm{A}^{-1-}$ embryos declined, and the number of embryo resorption sites increased. Most of the $\mathrm{A}^{-/-}$embryos died between days 11.5 and 14.5 p.c. The lethality was not universal, however. When litters from many heterozygote matings were followed to adulthood, the number of surviving $\mathrm{A}^{-1-}$ mice was about $14 \%$ of the expected value. The observed proportion of $+/+$ : $+/-$ : $-/-$ mice was $86 / 180 / 12$, when the expected proportion is $1 / 2 / 1$. We also found an abnormally small number of $\mathrm{A}^{-/-}$ animals when $\mathrm{A}^{-1-}$ males were bred to $\mathrm{A}^{+/-}$females.

Heterozygous matings between $\mathrm{B}^{+/-}$mice also produced a reduced number of $-/-$ offspring, but the lethality was not as severe as with the $\mathrm{A}^{-/-}$mice (Table I). $\mathrm{B}^{+/-} \times \mathrm{B}^{+/-}$matings produced $\sim 50 \%$ of the expected number of $\mathrm{B}^{-1-}$ offspring, as did matings between $\mathrm{B}^{-1-}$ males and $\mathrm{B}^{+/-}$females.

The surviving $\mathrm{A}^{-/-}$mice and $\mathrm{B}^{-/-}$mice were physically indistinguishable from their wild-type or heterozygous littermates. The total body weights of adults were normal, as were the weights of the liver and epididymal fat pads (Table II). The content of cholesterol in the liver was elevated 1.5-fold in both the $\mathrm{A}^{-1-}$ mice and the $\mathrm{B}^{-/-}$mice, and this difference was statistically significant. The liver triglyceride content was normal. Total plasma cholesterol was reduced slightly in both the $\mathrm{A}^{-1-}$ and $\mathrm{B}^{-1-}$ mice, but the difference was statistically significant only in the $\mathrm{B}^{-1-}$ animals $(P<0.001)$. Plasma triglycerides were also slightly lower in both types of knockout animals.

Fig. 2 compares immunoblots of membrane fractions and nuclear extracts in wild-type mice $(+/+)$ and in $\mathrm{A}^{-1-}$ or $\mathrm{B}^{-1-}$ mice. When blotted with a polyclonal antibody against amino

Table II. Phenotypic Comparison of Wild-type and SREBP-1 Knockout Mice

\begin{tabular}{|c|c|c|c|c|}
\hline \multirow[b]{2}{*}{ Parameter } & \multicolumn{2}{|c|}{ Disrupted allele A } & \multicolumn{2}{|c|}{ Disrupted allele B } \\
\hline & $+1+$ & $-1-$ & $+1+$ & $-1-$ \\
\hline Sex & 3 males, 3 females & 3 males, 3 females & 3 males, 3 females & 3 males, 3 females \\
\hline Body weight (g) & $32.2 \pm 2.1$ & $32.6 \pm 2.5$ & $27.7 \pm 1.7$ & $26.2 \pm 1.8$ \\
\hline Liver weight $(\mathrm{g})$ & $1.4 \pm 0.1$ & $1.4 \pm 0.1$ & $1.2 \pm 0.07$ & $1.2 \pm 0.07$ \\
\hline Liver weight / body weight & $0.043 \pm 0.002$ & $0.044 \pm 0.002$ & $0.044 \pm 0.001$ & $0.046 \pm 0.002$ \\
\hline Epididymal fat weight / body weight & $0.02 \pm 0.005$ & $0.02 \pm 0.01$ & $0.014 \pm 0.003$ & $0.011 \pm 0.002$ \\
\hline Liver cholesterol content $(\mathrm{mg} / \mathrm{g})$ & $2.7 \pm 0.2$ & $4.2 \pm 0.5(P<0.05)^{*}$ & $2.6 \pm 0.3$ & $3.9 \pm 0.2(P<0.0004)^{*}$ \\
\hline Liver triglyceride content $(\mathrm{mg} / \mathrm{g})$ & $20 \pm 5.3$ & $15 \pm 1.9$ & $17.5 \pm 2.7$ & $16.9 \pm 4.0$ \\
\hline Total plasma cholesterol (mg/dl) & $96.5 \pm 14$ & $75.3 \pm 10$ & $131 \pm 8.4$ & $89 \pm 5.7(P<0.001)^{*}$ \\
\hline Total plasma triglycerides $(\mathrm{mg} / \mathrm{dl})$ & $79 \pm 12$ & $62 \pm 3$ & $92 \pm 10$ & $64 \pm 6(P<0.05)^{*}$ \\
\hline
\end{tabular}

Each value represents the mean \pm SEM. Wild-type animals were littermates of knockout mice. The $-1-$ mice from disrupted allele A were 29-39 wk old (five mice from one line and one mouse from another line), and those from disrupted allele B, were 14-17 wk old (all mice from same line). Plasma lipids were measured on nonfasted samples. *Values in parentheses denote the level of statistical significance (Student's $t$ test). For parameters in which the level of significance is $P>0.05$, no values are shown. 


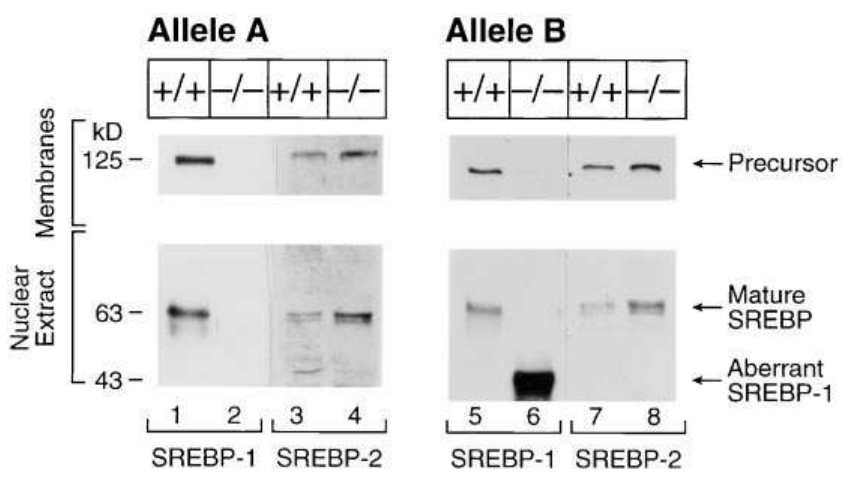

Figure 2. Immunoblot analysis of SREBP-1 and SREBP-2 in membranes and nuclear extracts from livers of wild-type mice $(+/+)$ and mice homozygous for disrupted SREBP-1 alleles A and B ( $-/-)$. For each group, livers from the six mice in Table II were pooled, and aliquots ( $30 \mu \mathrm{g}$ protein) of the membrane and nuclear extract fractions were subjected to $8 \%$ SDS-PAGE. Immunoblot analysis was performed as described in Methods using $5 \mu \mathrm{g} / \mathrm{ml}$ of rabbit anti-mouse SREBP-1 IgG or SREBP-2 IgG as the primary antibody and $0.25 \mu \mathrm{g} / \mathrm{ml}$ horseradish peroxidase-labeled donkey anti-rabbit IgG (Amersham Corp.) as the secondary antibody. Filters were exposed to film for $15 \mathrm{~s}$ (SREBP-1) or $60 \mathrm{~s}$ (SREBP-2) at room temperature.

acids $32-250$ of SREBP-1a (equivalent to 8-226 of SREBP1c), the $\mathrm{A}^{-1-}$ mice showed no immunoreactive band either in the membranes or the nuclear extract. This lack of immunoreactivity was confirmed when immunoblot analysis was carried out with a monoclonal antibody (IgG-2A4) directed against amino acids 301-407 of human SREBP-1a encoding exons 5-7 (15). This antibody cross reacts with mouse SREBP-1 in wild-type liver and thus would be expected to recognize an aberrant protein if it were produced (data not shown). The amount of SREBP-2 in the nuclear extract was increased two- to threefold as compared with normal mice. The membrane fractions from the $\mathrm{B}^{-/-}$mice also contained no detectable SREBP-1 precursor. However, the nuclear extract contained an immunoreactive protein of $\sim 40-\mathrm{kD}$. The mature form of SREBP-2 was increased two- to threefold in the nuclear extracts of the $\mathrm{B}^{-/-}$ mice just as it was in the $\mathrm{A}^{-1-}$ mice. Similar increases in mRNA and protein levels (1.5- to 4-fold) were observed in the three independent lines of mice that carried the disrupted $\mathrm{B}$ allele. We were unable to study each of the four lines carrying the A allele because of the limited number of surviving $-/-$ mice.

To confirm the identity of the shortened form of SREBP-1 in the $\mathrm{B}^{-l-}$ mice, we performed PCR on first-strand cDNA synthesized from mRNA obtained from the liver of a $\mathrm{B}^{-1-}$ mouse. We used $5^{\prime}$ primers derived from the $5^{\prime}$ ends of either SREBP-1a or -1 c. The $3^{\prime}$ primer was derived from the PolII promoter sequence that was present in the neo cassette of Targeting Construct B (Fig. $1 \mathrm{~B}$ ). The PCR products were cloned, and the ends were sequenced. As shown in Fig. $1 C$, the clones contained the authentic sequences of SREBP-1a or $-1 \mathrm{c}$ at the $5^{\prime}$ end. The $3^{\prime}$ ends contained the sequence of SREBP-1 up through the codon encoding amino acid 320 in SREBP-1c, which corresponds to amino acid 344 in SREBP-1a. Thereafter, the sequence extended into the sequence of the PolII promoter, which was part of the inserted neo cassette. The reading frame remained open for 23 amino acids. The proteins produced by these transcripts contain the basic region and part of the first helix of the HLH-Zip motif (Fig. $1 C$ ). Such proteins would not be expected to bind to the SRE or to affect transcription (15).

To determine whether any of the SREBP-1 transcripts in the $\mathrm{B}^{-1-}$ mice contain the $3^{\prime}$ end of the SREBP mRNA, we performed a series of northern blots on liver mRNA from the $\mathrm{B}^{-1-}$ mice. These blots revealed a $2.1-\mathrm{kb}$ transcript that was visualized with a cDNA probe complementary to the region of the SREBP-1c mRNA encoding amino acids 12-354 (see below in discussion of Fig. 4). The same transcript was visualized with a probe from the coding region of the neo gene, but it was not visualized with probes directed against the $\mathrm{COOH}$-terminal region of the SREBP-1 gene (data not shown). These data suggest that the transcript continues through the neo cassette and terminates at the $\operatorname{poly}(\mathrm{A})^{+}$signal within this cassette. Such a transcript is predicted to be $2.1-\mathrm{kb}$ in size, which is consistent with the $\sim 2$-kb mRNA observed in the Northern blots. The predicted molecular mass of the truncated SREBP-1c protein is $35 \mathrm{kD}$, which is consistent with the band of $\sim 40 \mathrm{kD}$ observed in immunoblots of nuclear extracts from the $\mathrm{B}^{-/-}$livers (Fig. 2).

To make certain that the protein products in the $\mathrm{B}^{-1-}$ mice are transcriptionally inactive, we prepared expression plasmids encoding these proteins, which contain either the SREBP-1a or $-1 \mathrm{c}$ sequences at their $\mathrm{NH}_{2}$ termini. Expression was driven by the TK promoter. To test the transcriptional activities of

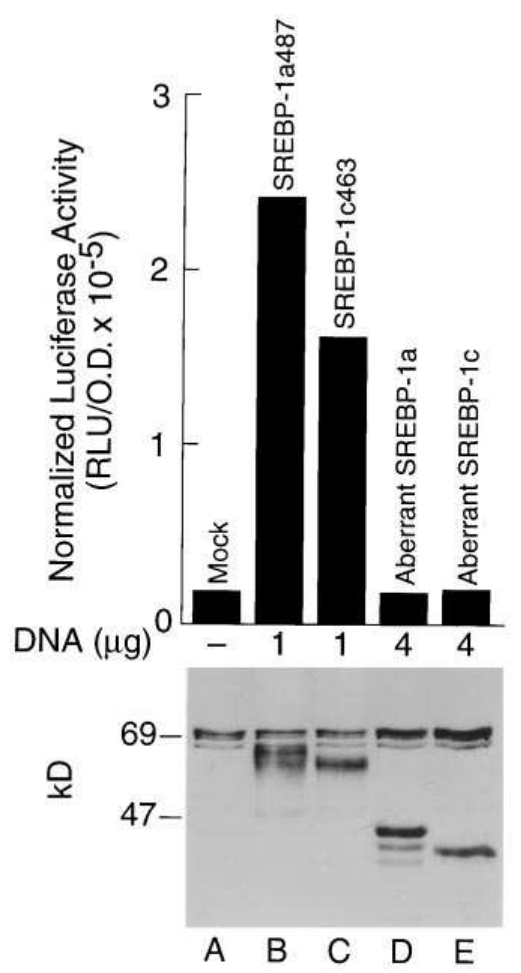

Figure 3. Stimulation of SRE-luciferase reporter gene by transfected aberrant SREBP-1 proteins driven by the TK promoter. 293 cells were set up for experiments as described in Methods and transfected with the indicated amount of pTK-SREBP-1a487, pTK-SREBP-1c463, pTK-aberrant SREBP$1 \mathrm{a}$, or pTK-aberrant SREBP-1c. A reporter pHMG CoA synthaseluc plasmid and a pCMV $\beta$-galactosidase reference plasmid were cotransfected as described in Methods. After transfection, all of the cells were cultured in medium A supplemented with $10 \%$ FCS, $1 \mu \mathrm{g} / \mathrm{ml} 25$-hydroxycholesterol, and $10 \mu \mathrm{g} / \mathrm{ml}$ cholesterol to suppress endogenous SREBP activity. After incubation for $16 \mathrm{~h}$, the cells were harvested, and luciferase activity was measured and normalized to $\beta$-galactosidase activity. Each value represents the average of duplicate incubations. Another duplicate set of dishes was harvested for immunoblot analysis. Nuclear extracts (30 $\mu \mathrm{g}$ protein) were prepared and subjected to $8 \%$ SDS-PAGE and immunoblotting with $5 \mu \mathrm{g} / \mathrm{ml}$ of rabbit anti-mouse SREBP-1 IgG as the primary antibody. The filter was exposed to film for $15 \mathrm{~s}$ at room temperature. The immunoreactive band at $69 \mathrm{kD}$ represents an irrelevant protein that cross reacts with the antibody in 293 cells. 
these proteins, we transfected the expression vectors into human 293 cells together with a reporter plasmid encoding luciferase under control of the HMG CoA synthase promoter (Fig. 3). The cells were incubated in the presence of sterols so as to prevent any influence from the endogenous SREBPs in the cells. As positive controls, we transfected plasmids encoding truncated versions of mouse SREBP-1a and -1c that included the complete bHLH-Zip domains. These proteins stimulated transcription as monitored by an increase in luciferase activity (Fig. 3, $B$ and $C$ ). In contrast, the aberrant SREBPs encoded by the disrupted genes failed to stimulate transcription (Fig. 3, $D$ and $E$ ). The bottom panel of Fig. 3 shows that all of these plasmids produced the appropriately sized proteins as determined by immunoblotting. The amount of protein produced by the aberrant plasmids was relatively low, and therefore we transfected the cells with four times as much DNA for these plasmids as opposed to the plasmids encoding the authentic truncated proteins.

Fig. 4 shows the relative levels of 15 mRNAs in livers of $+/+$, $\mathrm{A}^{-1-}$, and $\mathrm{B}^{-1-}$ mice as determined by northern blotting. The $\mathrm{A}^{-1-}$ mice produced two aberrant versions of SREBP-1 mRNA that blotted with the probe, which was derived from the $\mathrm{NH}_{2}$ domain of the SREBP-1 cDNA (corresponding to amino acids 12 to 354 of SREBP-1c). Neither of the aberrant SREBP-1 mRNAs in the $\mathrm{A}^{-1-}$ mice produced immunodetectable protein as revealed by the immunoblots of Fig. 2. As mentioned above, the $\mathrm{B}^{-1-}$ mice produced a shortened mRNA of $2 \mathrm{~kb}$, which encoded aberrant forms of SREBP-1. The results of all of the other northern blots were similar in the $\mathrm{A}^{-1-}$ and $\mathrm{B}^{-1-}$ mice.

The mRNA for SREBP-2 was elevated by about 1.5 -fold in both the $\mathrm{A}^{-1-}$ mice and the $\mathrm{B}^{-1-}$ mice (Fig. 4). This is consistent with the two- to threefold elevation in the levels of SREBP-2 protein in the nuclear extract as determined by immunoblotting (Fig. 2). The mRNA for the LDL receptor was elevated slightly in the $\mathrm{A}^{-/-}$and $\mathrm{B}^{-/-}$mice (1.2- to 1.3 -fold) (Fig. 4), but this is of questionable biological significance. The elevations in mRNAs encoding cholesterol biosynthetic enzymes were more impressive (2.1- to 3.8-fold for HMG CoA synthase, HMG CoA reductase, farnesyl diphosphate synthase, and squalene synthase) (Fig. 4).

In contrast to the consistent increase in the mRNAs for cholesterol synthetic enzymes, the mRNAs for three enzymes involved in fatty acid synthesis were either normal or slightly reduced in the $\mathrm{A}^{-1-}$ and $\mathrm{B}^{-1-}$ mice (Fig. 4). These mRNAs encoded acetyl CoA carboxylase, fatty acid synthase and stearoyl CoA desaturase-1. The mRNAs for apoAI, apoB, and apoE were essentially unchanged in the knockout animals. The mRNA encoding microsomal triglyceride transfer protein, which is necessary for assembly of VLDL, was unchanged in the knockout animals. Results similar to those in Fig. 4 were obtained on two different occasions when the mRNAs of pooled wild-type and knockout animals were examined.

Fig. 5 shows measurements of $13 \mathrm{mRNAs}$ in adipose tissue derived from epididymal fat pads and paramesenteric fat tissue of the $\mathrm{B}^{-1-}$ knockout mice. As expected, the $\mathrm{B}^{-1-}$ mice produced the $2-\mathrm{kb}$ aberrant transcript of SREBP-1. In contrast to the situation in liver, the level of SREBP-2 mRNA in adipose tissue was very low, and it was not elevated detectably in the $\mathrm{B}^{-1-}$ mice. There was a slight increase in mRNAs for the LDL receptor (1.4-fold) and a more clear-cut 2.4-fold elevation in squalene synthase. The levels of other mRNAs were essentially normal except for a $50 \%$ reduction in the mRNA for stearoyl CoA desaturase. In particular, there was no significant change in the mRNAs for a group of proteins that are relatively adipose-specific, including LPL, hormone-sensitive lipase, $\mathrm{aP} 2$, and leptin.

To determine the effects of the SREBP-1 gene disruption on overall patterns of lipid synthesis, we injected $+/+$ and $\mathrm{B}^{-1-}$

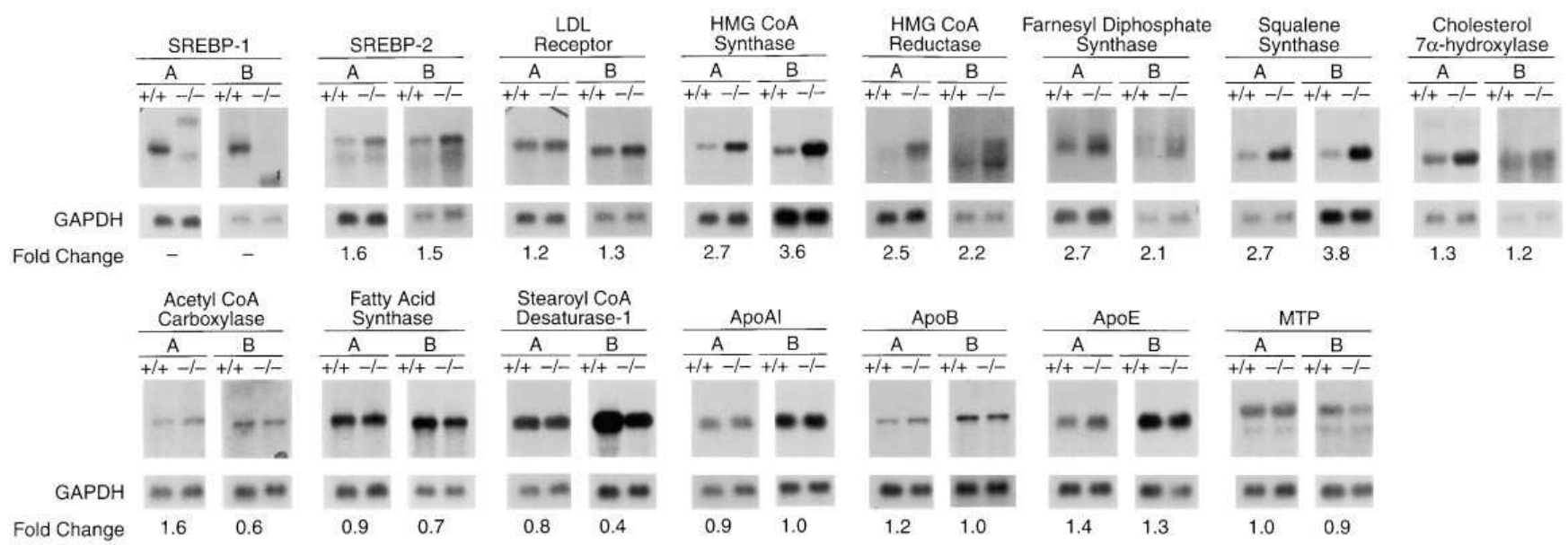

Figure 4. Amounts of various mRNAs in livers of wild-type mice $(+/+)$ and mice homozygous $(-/-)$ for disrupted SREBP-1 allele A $(A)$ and allele $\mathrm{B}(B)$ as measured by blot hybridization. Total liver RNA isolated from the six mice in Table II was pooled and $15 \mu \mathrm{g}$ aliquots were subjected to electrophoresis and blot hybridization with the indicated ${ }^{32} \mathrm{P}$-labeled probe. The amount of radioactivity in each band was quantified as described in Methods. The Fold Change in each mRNA of $-/-$ mice, relative to that of the respective wild-type mice, was calculated after correction for loading differences with GAPDH. These values are shown below each blot except for SREBP-1. Two aberrant signals of SREBP-1 mRNA were observed in livers from mutant mice harboring disrupted allele A. The two transcripts differ in length as a result of the presence or absence of the disrupted exon 2/neo cassette, as determined by hybridization with a neo probe and sequencing of reverse transcriptase-PCR products. No significant amounts of protein products from these two aberrant mRNAs were detected in immunoblot analysis of liver nuclear extracts or membranes (see Fig. 2). One aberrant SREBP-1 mRNA was detected in livers from mutant mice harboring allele B. This mRNA was translated into an aberrant protein that was detected in nuclear extracts (see Fig. 2). 


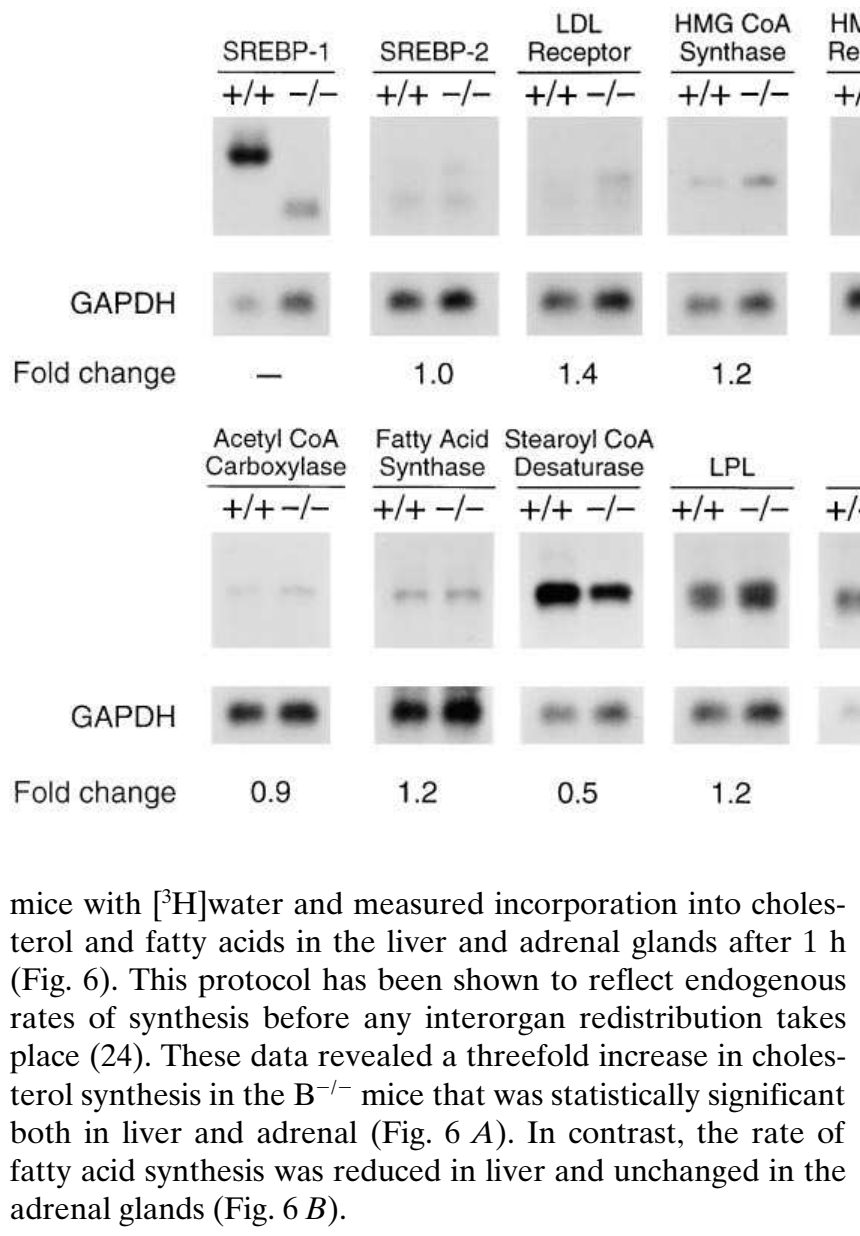

\section{Discussion}

These experiments have produced several new observations with respect to the actions of SREBPs in livers of intact animals: (a) most mice homozygous for a disruption of the SREBP-1 gene died in utero around embryonic day 11; $(b)$
Figure 5. Amount of various mRNAs in white adipose tissues of wild-type mice $(+/+)$ and mice homozygous for disrupted SREBP-1 allele $\mathrm{B}(-/-)$ as measured by blot hybridization. Total RNA isolated from epididymal fat pads or paramesenteric fat of the six mice in Table II (Construct B) was pooled, and $15 \mu \mathrm{g}$ aliquots were subjected to electrophoresis and blot hybridization with the indicated ${ }^{32} \mathrm{P}$-labeled probe. The amount of radioactivity in each band was quantified as described in Methods. The Fold change in each mRNA of $-1-$ mice, relative to that of wild-type mice, was calculated after correction for loading differences with GAPDH. These values are shown below each blot. The probe for stearoyl CoA desaturase (SCD) was the mouse SCD-1 cDNA fragment (13) that can detect both SCD-1 and SCD-2 mRNA in adipose tissue. surviving $-/-$ mice appeared physically normal at birth and throughout adulthood; $(c)$ the survivors manifested elevated levels of SREBP-2 mRNA in liver and an elevated level of the mature form of SREBP-2 in liver nuclei; $(d)$ the survivors had elevated levels of hepatic mRNAs for enzymes of cholesterol synthesis, but not fatty acid synthesis; $(e)$ the survivors overproduced cholesterol in liver and adrenal gland; and $(f)$ plasma cholesterol and triglycerides in the survivors were slightly reduced.

The cause of the embryonic lethality in the SREBP-1 knockout mice is not clear. Most of the deaths occurred between embryonic day 11.5 and 14.5. Histologic examination of embryos at days 8.5 and 9.5 failed to reveal aberrant development of any organs. In unpublished experiments we observed mortality at embryonic days 7-8 in mice homozygous for a disruption of the SREBP-2 gene. In contrast to the SREBP-1 disruption, we

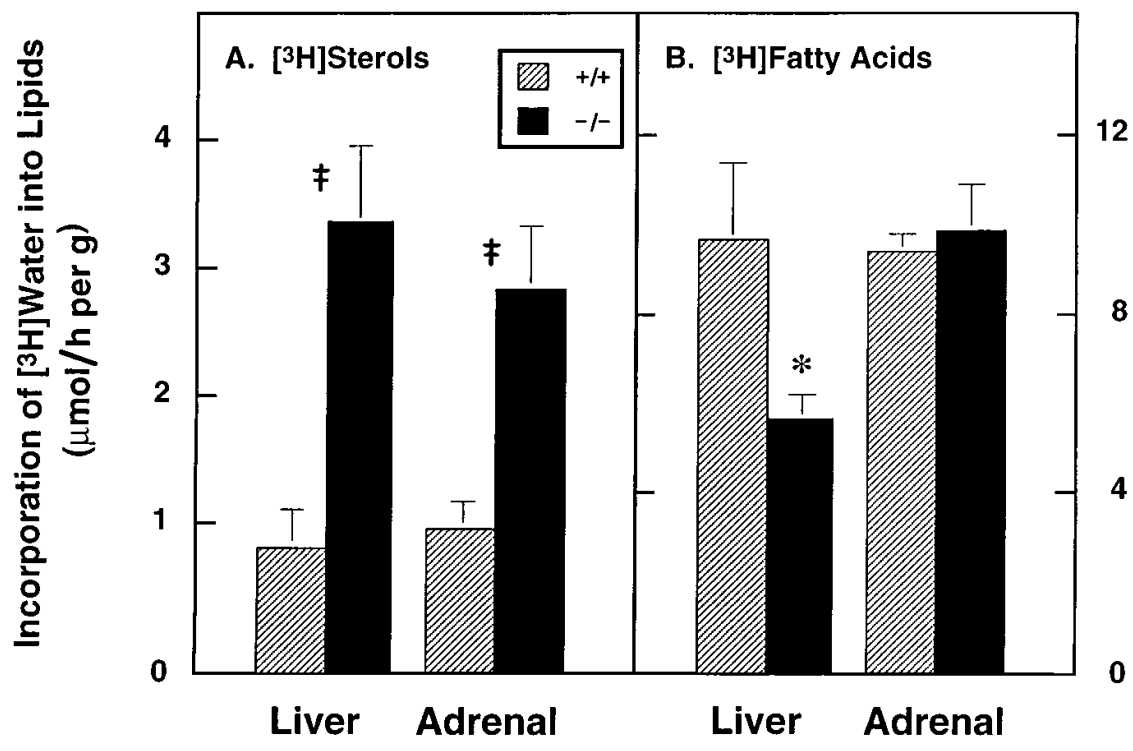

Figure 6. In vivo synthesis of cholesterol and fatty acids in liver and adrenal glands from 8 wild-type mice $(+/+)$ and mice homozygous for disrupted SREBP-1 allele B (-/-). Each value represents the mean of eight 20 -wk-old mice (four females and four males) of the indicated genotype. $\left[{ }^{3} \mathrm{H}\right]$ Water $(50 \mathrm{mCi}$ in $0.25 \mathrm{ml}$ of isotonic saline) was injected intraperitoneally, and $1 \mathrm{~h}$ later the indicated tissue was removed for measurement of its contents of ${ }^{3} \mathrm{H}$-labeled digitonin-precipitable sterols and fatty acids as described in Methods. Bars denote mean \pm SEM. * and ${ }^{\ddagger}$ denote the levels of statistical significance (Student's $t$ test) at $P<$ 0.05 and $P<0.01$, respectively. 
observed no liveborn mice homozygous for SREBP-2 disruptions. ${ }^{2}$

Among the SREBP-1 knockout mice, lethality appeared to be somewhat greater in the $\mathrm{A}^{-1-}$ mice than in the $\mathrm{B}^{-1-}$ mice (prenatal mortality 85 versus $50 \%$ ). The reason for this difference is not clear. Both disruptions appeared to destroy SREBP-1 function. In the $\mathrm{A}^{-1-}$ mice no immunodetectable SREBP-1 was produced. The $\mathrm{B}^{-1-}$ mice produced a truncated form of SREBP-1 that lacked most of the HLH-Zip domain. Transfection experiments demonstrated that this protein fragment was unable to stimulate transcription from a sterol regulatory element-dependent promoter (Fig. 3). The biochemical abnormalities in livers of surviving mice were indistinguishable in the $\mathrm{A}^{-1-}$ mice and the $\mathrm{B}^{-1-}$ mice, indicating that both types of animals were equally deficient in SREBP-1 activity.

It seems likely that some of the SREBP-1 knockout mice survive because SREBP-2 compensates for the deficit of SREBP-1. We do not know whether SREBP-2 is overproduced as a direct regulatory response to a deficiency of SREBP-1, or whether this overproduction is a result of selection. The expression of SREBP-2 may vary among all animals depending on their genetic background, and those SREBP-1 $1^{-/-}$ animals that happened to express high levels of SREBP-2 by chance may have had a survival advantage in utero. Interestingly, although SREBP-2 appears able to substitute for SREBP-1, the reverse is not true. Thus, all SREBP-2 $2^{-1-}$ mice died in utero even though the gene for SREBP-1 was intact. ${ }^{2}$ This failure may be due to the failure of SREBP-1 to be expressed during embryogenesis in some organ that expresses SREBP-2. Alternatively, it is possible that SREBP-2 can activate some crucial gene in a way that neither SREBP-1a nor SREBP-1c can duplicate.

The increased mRNAs for the cholesterologenic enzymes are most likely attributable to the demonstrated increase in SREBP-2 in the nucleus. The liver normally produces predominantly the 1c isoform of SREBP-1 (11), which is a very weak activator of transcription of cholesterologenic enzymes (8). The elimination of this weak activator and its replacement by the strong activator, SREBP-2, would be expected to lead to an increase in mRNAs for cholesterologenic enzymes. An opposite effect was observed for the enzymes of fatty acid biosynthesis. Here SREBP-1c has definite stimulating activity (8). Thus, the replacement of SREBP-1c with SREBP-2 does not lead to an increase in the enzymes of fatty acid biosynthesis.

The increase in mRNAs for cholesterologenic enzymes was matched by an increase in the overall rate of cholesterol synthesis in the livers of the $\mathrm{B}^{-1-}$ mice (Fig. 6). This overproduction of cholesterol was also reflected by an increase in the content of cholesterol in the livers of these animals (Table II). Remarkably, plasma cholesterol levels were not elevated, and indeed they were slightly decreased in both the $\mathrm{A}^{-/-}$and $\mathrm{B}^{-/-}$ animals. So far, none of the manipulations of SREBPs in mouse liver has led to profound changes in plasma lipid levels. This includes overexpression of dominantly active SREBP-1a and SREBP-1c $(8,13)$, as well as targeted disruption of the SREBP-1 gene. The liver of the mouse normally produces high levels of LDL receptors, which keep the plasma concentration

2. Horton, J.D., H. Shimano, M.S. Brown, and J.L. Goldstein, unpublished data. of LDL and intermediate density lipoproteins (IDL) very low (16). Disruption of the LDL receptor gene by homologous recombination leads to massive hypercholesterolemia, especially when the animals are fed a cholesterol-rich diet (25).

It is noteworthy that the SREBP-1 knockout mice had normal amounts of adipose tissue (Table II) that expressed normal amounts of several adipocyte-specific mRNAs (Fig. 5). Although adipose tissue normally produces only a small amount of SREBP-2, it is possible that this is sufficient to compensate for the loss of SREBP-1. Alternatively, it is possible that the SREBPs are not required for adipocyte differentiation and that their roles can be filled by other factors.

A definitive answer regarding the role of SREBPs in liver and adipose tissue awaits the production of animals in which the SREBP-1 and SREBP-2 genes are both inactivated. This cannot be accomplished by conventional methods of homologous recombination since the loss of SREBP-2 alone is an embryonic lethal. ${ }^{2}$ Presently, we are preparing vectors that will allow conditional inactivation of the SREBP-2 gene in adult animals through use of the cre/lox recombination system (26). This should allow an examination of the acute effects of SREBP-2 inactivation, and it should then be possible to prepare mice that can be deleted for both SREBP-1 and SREBP-2.

\section{Acknowledgments}

We thank Yuri Bashmakov, Scott Clark, and Robin Craddock for excellent technical assistance; Richard Gibson and Laura Quinlivan for invaluable help with the animals; Dr. James Richardson and John Shelton for help with tissue histology; and Dr. Laura Woollett for help with the $\left[{ }^{3} \mathrm{H}\right]$ water experiment.

This work was supported by grants from the National Institutes of Health (HL-20948), the Moss Heart Foundation, and the Perot Family Foundation. J.D. Horton is the recipient of a Postdoctoral Fellowship for Physicians from the Howard Hughes Medical Institute. I. Shimomura is the recipient of a Research Fellowship from the Manpei Suzuki Diabetes Foundation of Tokyo, Japan. J. Herz is the recipient of an Established Investigator Award from the American Heart Association and Parke-Davis Co.

\section{References}

1. Brown, M.S., and J.L. Goldstein. 1997. The SREBP pathway: regulation of cholesterol metabolism by proteolysis of a membrane-bound transcription factor. Cell. 89:331-340.

2. Sakai, J., E.A. Duncan, R.B. Rawson, X. Hua, M.S. Brown, and J.L. Goldstein. 1996. Sterol-regulated release of SREBP-2 from cell membranes requires two sequential cleavages, one within a transmembrane segment. Cell. 85: 1037-1046.

3. Yang, J., M.S. Brown, Y.K. Ho, and J.L. Goldstein. 1995. Three different rearrangements in a single intron truncate SREBP-2 and produce sterol-resistant phenotype in three cell lines. J. Biol. Chem. 270:12152-12161.

4. Sheng, Z., H. Otani, M.S. Brown, and J.L. Goldstein. 1995. Independent regulation of sterol regulatory element binding proteins 1 and 2 in hamster liver. Proc. Natl. Acad. Sci. USA. 92:935-938.

5. Hua, X., J. Sakai, Y.K. Ho, J.L. Goldstein, and M.S. Brown. 1995. Hairpin orientation of sterol regulatory element binding protein-2 in cell membranes as determined by protease protection. J. Biol. Chem. 270:29422-29427.

6. Chang, T.Y., M.T. Hasan, J. Chin, C.C.Y. Chang, D.M. Spillane, and J. Chen. 1997. CHO cell mutants affecting cholesterol metabolism. Curr. Opin. Lipidol. 8:65-71.

7. Hua, X., J. Wu, J.L. Goldstein, M.S. Brown, and H.H. Hobbs. 1995. Structure of human gene encoding sterol regulatory element binding protein-1 (SREBF1) and localization of SREBF1 and SREBF2 to chromosomes 17p11.2 and 22q13. Genomics. 25:667-673.

8. Shimano, H., J.D. Horton, I. Shimomura, R.E. Hammer, M.S. Brown, and J.L. Goldstein. 1997. Isoform 1c of sterol regulatory element binding protein is less active than isoform 1a in livers of transgenic mice and in cultured cells. J. Clin. Invest. 99:846-854. 
9. Miserez, A.R., G. Cao, L. Probst, and H.H. Hobbs. 1997. Structure of the human gene encoding sterol regulatory element binding protein 2 (SREBF2). Genomics. 40:31-40.

10. Hua, X., C. Yokoyama, J. Wu, M.R. Briggs, M.S. Brown, J.L. Goldstein, and X. Wang. 1993. SREBP-2, a second basic-helix-loop-helix-leucine zipper protein that stimulates transcription by binding to a sterol regulatory element. Proc. Natl. Acad. Sci. USA. 90:11603-11607.

11. Shimomura, I., H. Shimano, J.D. Horton, J.L. Goldstein, and M.S. Brown. 1997. Differential expression of exons 1a and 1c in mRNAs for sterol regulatory element binding protein-1 in human and mouse organs and cultured cells. J. Clin. Invest. 99:838-845.

12. Kim, J.B., and B.M. Spiegelman. 1996. ADD1/SREBP1 promotes adipocyte differentiation and gene expression linked to fatty acid metabolism. Genes Dev. 10:1096-1107.

13. Shimano, H., J.D. Horton, R.E. Hammer, I. Shimomura, M.S. Brown, and J.L. Goldstein. 1996. Overproduction of cholesterol and fatty acids causes massive liver enlargement in transgenic mice expressing truncated SREBP-1a. J. Clin. Invest. 98:1575-1584.

14. Sambrook, J., E.F. Fritsch, and T. Maniatis. 1989. Molecular Cloning: A Laboratory Manual. Cold Spring Harbor Laboratory Press, New York.

15. Sato, R., J. Yang, X. Wang, M.J. Evans, Y.K. Ho, J.L. Goldstein, and M.S. Brown. 1994. Assignment of the membrane attachment, DNA binding, and transcriptional activation domains of sterol regulatory element binding protein-1 (SREBP-1). J. Biol. Chem. 269:17267-17273.

16. Ishibashi, S., M.S. Brown, J.L. Goldstein, R.D. Gerard, R.E. Hammer, and J. Herz. 1993. Hypercholesterolemia in LDL receptor knockout mice and its reversal by adenovirus-mediated gene delivery. J. Clin. Invest. 92:883-893.

17. Spear, D.H., S.Y. Kutsunai, C.C. Correll, and P.A. Edwards. 1992. Molecular cloning and promoter analysis of the rat liver farnesyl diphosphate syn- thase gene. J. Biol. Chem. 267:14462-14469.

18. Lin, M.C.M., C. Arbeeny, K. Bergquist, B. Kienzle, D.A. Gordon, and J.R. Wetterau. 1994. Cloning and regulation of hamster microsomal triglyceride transfer protein. J. Biol. Chem. 269:29138-29145.

19. Kirchgessner, T.G., K.L. Svenson, A.J. Lusis, and M.C. Schotz. 1987. The sequence of cDNA encoding lipoprotein lipase: a member of a lipase gene family. J. Biol. Chem. 262:8463-8466.

20. Li, Z., M. Sumida, A. Birchbauer, M.C. Schotz, and K. Reue. 1994. Isolation and characterization of the gene for mouse hormone-sensitive lipase. $G e-$ nomics. 24:259-265.

21. Zhang, Y., R. Proenca, M. Maffei, M. Barone, L. Leopold, and J.M. Friedman. 1994. Positional cloning of the mouse obese gene and its human homologue. Nature (Lond.). 372:425-432.

22. Hunt, C.R., J.H.-S. Ro, D.E. Dobson, H.Y. Min, and B.M. Spiegelman 1986. Adipocyte P2 gene: developmental expression and homology of 5 '-flanking sequences among fat cell-specific genes. Proc. Natl. Acad. Sci. USA. 83: 3786-3790.

23. Chomczynski, P., and N. Sacchi. 1987. Single-step method of RNA isolation by acid guanidinium thiocyanate-phenol-chloroform extraction. Anal. Biochem. 162:156-159.

24. Osono, Y., L.A. Woollett, J. Herz, and J.M. Dietschy. 1995. Role of the low density lipoprotein receptor in the flux of cholesterol through the plasma and across the tissues of the mouse. J. Clin. Invest. 95:1124-1132.

25. Ishibashi, S., J.L. Goldstein, M.S. Brown, J. Herz, and D.K. Burns. 1994 Massive xanthomatosis and atherosclerosis in cholesterol-fed LDL receptornegative mice. J. Clin. Invest. 93:1885-1893.

26. Kuhn, R., F. Schwenk, M. Aguet, and K. Rajewsky. 1995. Inducible gene targeting in mice. Science (Wash. DC). 269:1427-1429. 